
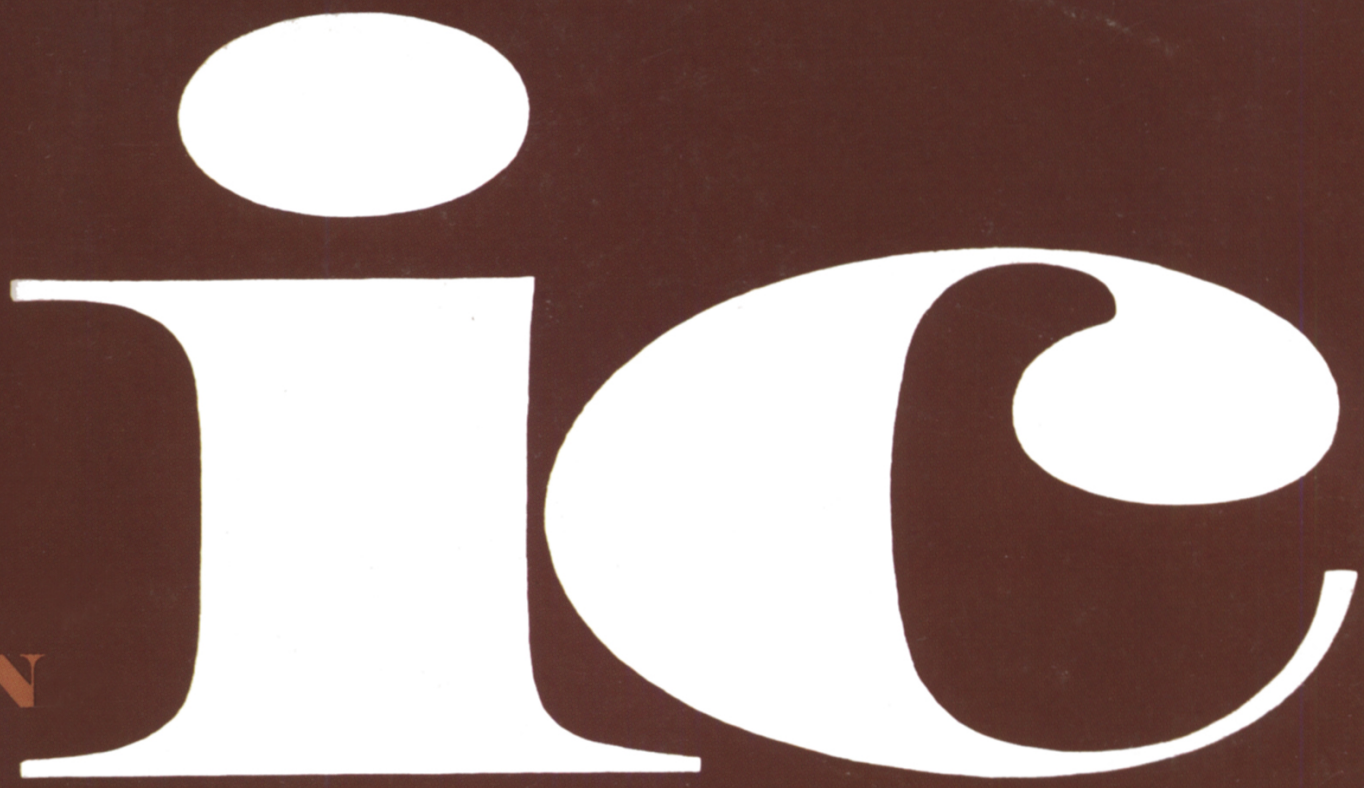

July/August 1983

Volume 4/Number 4

CDC Guideline for Isolation

Precautions in Hospitals

Julia S. Garner, RN, MS and

Bryan P. Simmons, MD

CDC Guideline for Infection Control in Hospital Personnel

Walter W. Williams, MD, MPH

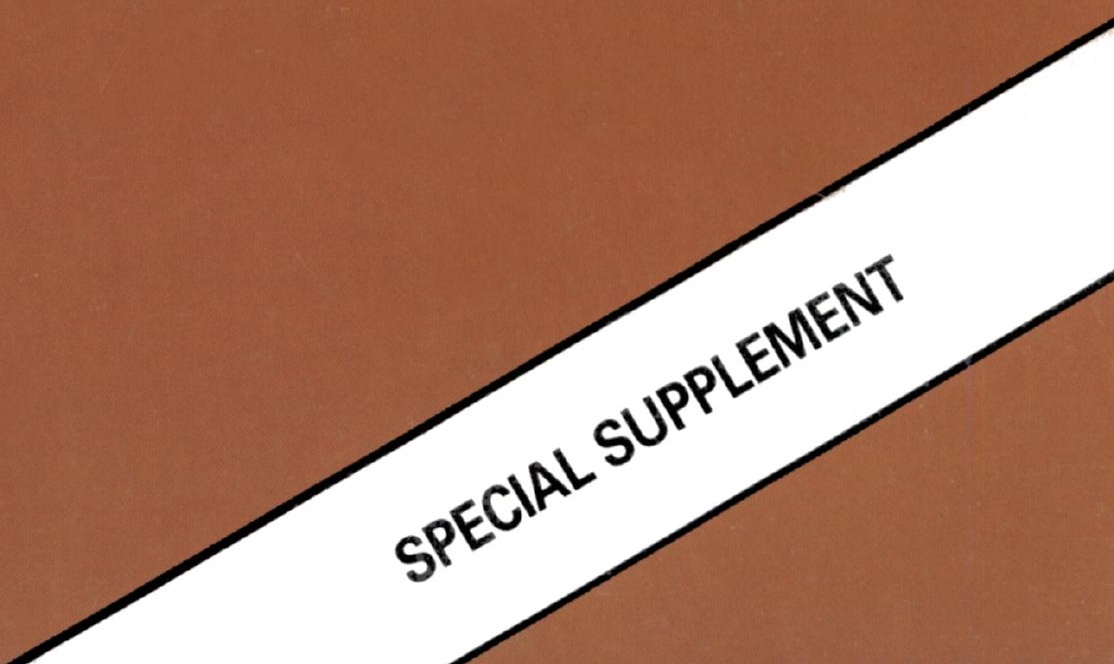




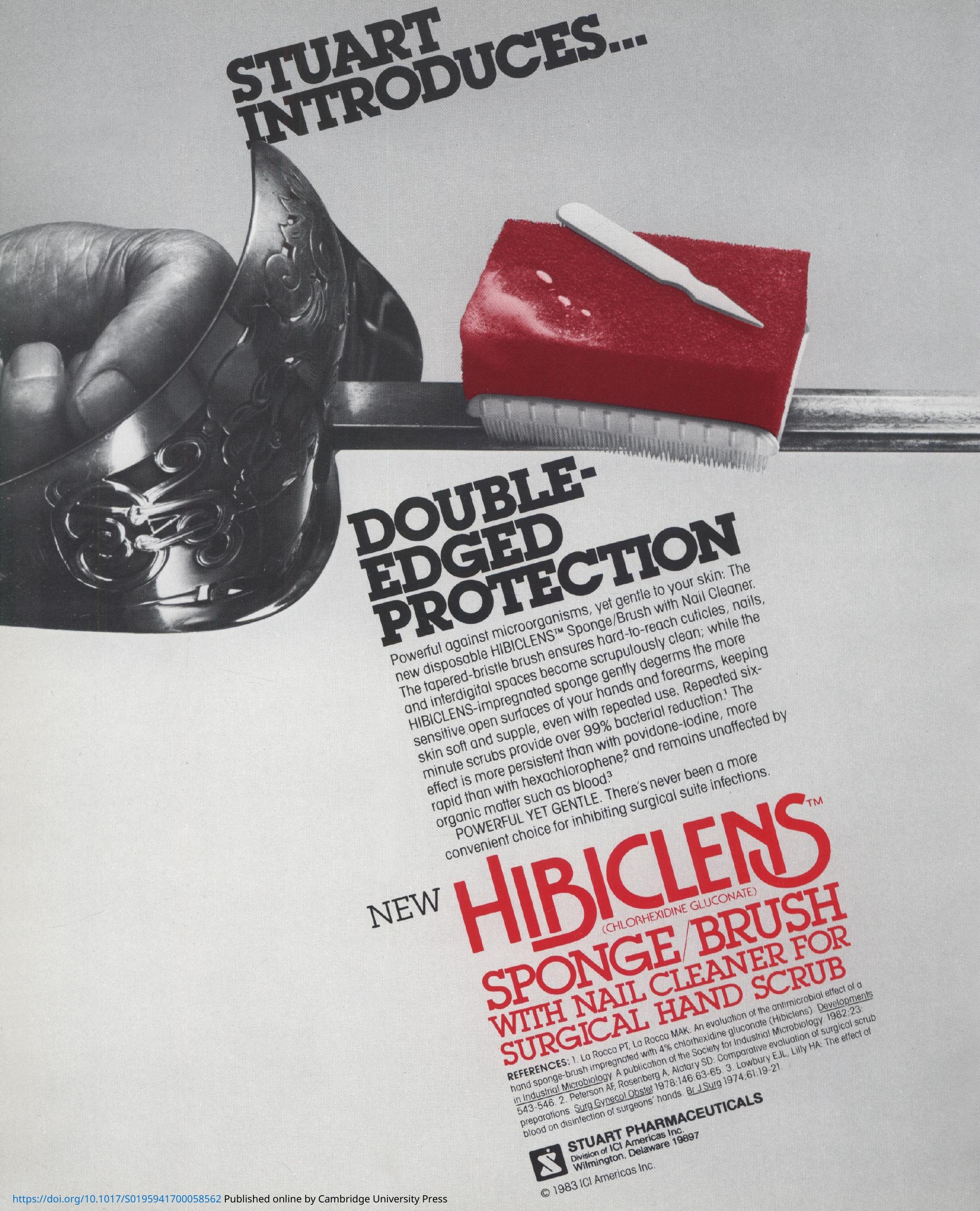




\title{
Guideline for Isolation Precautions in Hospitals
}

\author{
Written by Julia S. Garner, RN, MN \\ Bryan P. Simmons, MD \\ Hospital Infections Program \\ Center for Infectious Diseases \\ Centers for Disease Control \\ Atlanta, Georgia
}

\author{
WORKING GROUP \\ Theodore C. Eickhoff, MD, Chairman \\ Professor of Medicine \\ University of Colorado School of Medicine \\ Director of Internal Medicine \\ Presbyterian/St. Luke's Medical Center \\ Denver, Colorado
}

James D. Cherry, MD

Professor of Pediatrics

Chief, Division of Pediatric Infectious Diseases

Center for the Health Sciences

UCLA School of Medicine

Los Angeles, California

William R. Cole, MD

Surgical Associates

Sedalia, Missouri

Richard E. Dixon, MD

Associate Professor of Medicine

Hahnemann University

Director, Department of Medicine

Helene Fuld Medical Center

Trenton, New Jersey

Mary Jane Freeburn, RN

Infection Control Nurse

Good Samaritan Hospital of Santa Clara Valley

San Jose, California
Rita D. McCormick, RN

Infection Control Nurse

University of Wisconsin Hospitals and Clinics

Madison, Wisconsin

John D. Nelson, MD

Professor of Pediatrics

University of Texas Health Science Center at Dallas

Dallas, Texas

Philip A. Pizzo, MD

Head, Infectious Diseases Section

Chief, Pediatric Branch

National Cancer Institute

National Institutes of Health

Bethesda, Maryland

William Schaffner, MD

Professor of Preventive Medicine and Medicine

Vanderbilt University School of Medicine

Nashville, Tennessee 
Robert W. Haley, MD

Director

James R. Allen, MD

Former Chief

Epidemic Investigations Branch

T. Grace Emori, RN, MS

Nurse Epidemiologist

Surveillance and Prevention Branch
James M. Hughes, MD

Assistant Director for Medical Science

William J. Martone, MD

Chief

Epidemic Investigations Branch

Walter W. Williams, MD

Chief

Guidelines Activity

\section{Other CDC Contributors}

Mary Louise Atkinson, RN, MA

Assistant to the Director (retired)

Division of Tuberculosis Control

Center for Prevention Services

Laurence S. Farer, MD

Director

Division of Tuberculosis Control

Center for Prevention Services
Martin S. Favero, PhD

Assistant Director for Laboratory Science Division of Hepatitis and Viral Enteritis Center for Infectious Diseases

Frances H. Porcher, Chief Gayle P. Lloyd, Writer-Editor Publications and Graphics Activities Center for Infectious Diseases 


\section{Contents}

Page

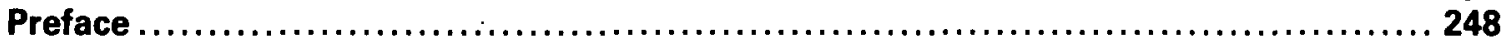

Section 1: Introduction ................................................. 249

Major Changes in the Guidelines for Isolation Precautions in Hospitals

from Previous Editions of Isolation Manual ..................................... 249

Deciding Which System of Isolation Precautions to Use in Your Hospital.............. 250

Section 2: Rationale and Responsibilities for Isolation Precautions................ 251

Section 3: Techniques and Recommendations for Isolation Precautions.............. 253

Techniques for Isolation Precautions ............................................. 253

Alternative Systems for Isolation Precautions ...................................... 258

System A. Category-Specific Isolation Precautions................................ 258

Table A. Category-Specific Isolation Precautions............................. 260

Sample Instruction Cards for Category-Specific Isolation Precautions ............. 284

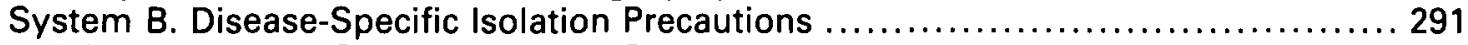

Table B. Disease-Specific Isolation Precautions ............................. 291

Sample Instruction Card for Disease-Specific Isolation Precautions ............... 323

Section 4: Modification of Isolation Precautions.................................. 324

Modification of Isolation Precautions in Intensive Care Units ....................... 324

Modification of Isolation Precautions for Newborns and Infants...................... 324

Care of Severely Compromised Patients ............................................. 325

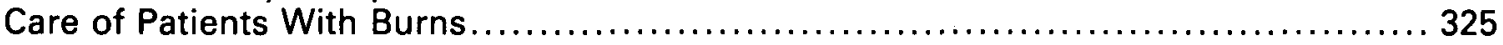

